\title{
SOME ASPECTS OF CIVIL LEGISLATION RECODIFICATION IN THE CONTEXT OF EUROPEAN INTEGRATION PROCESSES
}

\section{Safonchik O. I.}

\section{INTRODUCTION}

The adoption of the Civil Code of Ukraine (hereinafter - CC of Ukraine) on 16.01.2003 testified to a fundamental change in the legal regulation of civil relations, which became the basis of private law of an independent Ukraine. The overwhelming majority of the rules of the CC of Ukraine is characterized by high legal technique, complete regulation of civil relations. A large number of novelties were introduced for all legal institutions, including the field of property law. At the same time, 16-year practice of application of Civil Code of Ukraine norms also revealed vulnerable provisions, contradictions, which necessitated many changes to make, the analysis of which gives grounds to confirm the continuous improvement of the civil legislation. However, in our view, the mechanism of regulation of individual relations requires further improvement in several directions, which is caused by the introduction of new objects of civil rights, the imperfection of legal norms revealed in the course of their application by the courts and the participants of civil legal relations; as well as Ukraine's aspirations for European integration.

Adaptation to the conditions of the EU internal market needs updating of civil law with a simultaneous solution to the general problem of choosing between the private (humanitarian) approach and the public-law (state-regulatory) approach.

These circumstances should be taken into account when defining the algorithm of adaptation of Ukraine to the EU legal system (at present it looks like a legal adaptation to the conditions of the EU internal market, which is, first and foremost, in the perception and adoption of the European concept of private law).At the same time, the problems of ideological and mental compatibility must also be resolved, without which the desired result of adaptation of justice, legal understanding, legal doctrine, legislation and, finally, the concept of law (in particular, private law) cannot be achieved.

It is well-known that any modern social activity needs more and more attention from the analysis and study of the nuances of its implementation, comprehensive examination of the economic status of counterparties, analysis of legal and title documents, investment characteristics of real estate objects, identification of possible risks of transactions and the possibility of reducing them. 
On the need for systematic update of Civil Code of Ukraine started talking at the beginning of 2019. The logical continuation of this process was the creation of a working group on the recodification (updating) of the civil legislation of Ukraine in the summer of 2019.

Currently, through the joint efforts of the world's leading experts, the best legal standards have been found for many areas of private legal relations. Such rules are embodied in numerous international instruments on the unification of private law. On this basis, the most recent modernization (and, at the same time, harmonization) of national civil codes and private law doctrines has begun in European countries. Thus, the global (especially European) tendency towards the unification and harmonization of private legal regulation is a significant factor in the modern updating of civil codes in many countries.

Of course, Ukraine cannot stay away from these world processes, so Ukrainian researchers have made efforts to identify major problems, gaps in civil law and develop proposals to improve the legal regulation of civil relations, as well as fill in the gaps. Particular interest were the problematic issues regarding the low level of modern legal technology observed in drafting bills, the possibility of introducing new private law institutions (negative obligations, the category of "error", etc.) into the domestic law, the archaic nature and blanket type of many other existing norms and other.

\section{Prospects of Ukraine civil legislation renewal in the area of property protection}

The traditional and most widely used ways of protecting property rights in Ukraine are a lawsuit to seize property from someone else's illegal possession (vindication lawsuit) and a lawsuit to remove obstacles to the use and disposal of property (negative lawsuit).At the same time, the terms "vindication" and "negative" lawsuits are not used in the Civil Code of Ukraine, despite the fact that such term is directly enshrined in separate legislative acts. In view of the well-established practice of applying these methods of protection and the unification of legislative acts governing the protection of property rights, articles 387 and 391 of the $\mathrm{CC}$ should be supplemented by the names of those methods of protection. Requires to solve the problem of competition vindication, restitution and conditioning, that laid down in art. 1212 of the $\mathrm{CC}^{1}$.Established in civil science and jurisprudence in the application of a negative claim is the position to not extending on such claims the limitation period. At the same time, the CC does not have an appropriate standard, which requires mandatory consideration when making changes to the $\mathrm{CC}$.

${ }^{1}$ Civil Code of Ukraine of May 10, 2018 (as amended and supplemented) // Official TextK. : PALIVODA AV, 2018. 408 p. 
Another problem of the $\mathrm{CC}$ in the field of property rights protection, which needs to be addressed when updating civil law, is the problem associated with the use of such a method of protection as recognition of property rights. According to art. 392 of the Civil Code, the property owner may bring an action for recognition of his property right, if this right is contested or not recognized by another person, and also in case of the loss of a document certifying his ownership. Unlike the first two grounds for recognition of title, the loss of the title deed may not be accompanied by a violation of the title of the owner, and may therefore even be considered as a preventive measure aimed at preventing a violation of title in the future, for example, by the person who found the lost title documents. Therefore, the recognition of property rights on grounds of loss of title documents has its own peculiarities, as well as certain problems that lie in the proper determination of the jurisdiction of the court to be addressed in such case; finding out the possibility of considering such case in a separate civil proceeding, failing separate trial and the jurisdiction of economic or administrative courts - determining the proper defendant, as well as the possibility of applying this method of protection of property rights, not only in case of legal documents loss, but also in in the absence of them at all. More information about these issues, see. Dzera I.O. Some issues of property rights recognition under art. 392 of the Civil Code of Ukraine ${ }^{2}$.

It should be noted other problems in applying this method of protection on the grounds of loss by the owner his title documents: 1) the inability to identify the defendant, because in this case the right of ownership is not disputed by anyone; 2) complication of determining the form of the procedure by the wording art. 392 of the Civil Code, according to which the owner of the property can sue for recognition of his ownership; 3) the reason for the application of this protection method may be not only the loss, but also the absence of the title document, unless it was issued at the time of acquisition by the person of ownership or the law did not provide for its receipt at all.

Solving these problems in court practice carried out in different ways. Thus, most often, as defendants are involved government or local selfgovernment, whose competence is the issuance of a legal document. At the same time with the adoption of the Code of Administrative Justice of Ukraine, such disputes are subject to resolution in the administrative procedure, which leads to problems in determining the jurisdiction of such cases. Exclusion from art. 392 of the Civil Code of the construction of "lawsuit" or its replacement by "statement" also does not fully solve the problem under study,

\footnotetext{
2 Дзера І.О. Деякі питання визнання права власності за статтею 392 Цивільного кодексу України. Підприємництвво, господарство і право. 2018 № 5. С. 19-24.
} 
because such cases can be heard in a separate proceeding only in civil proceedings. In the presence of economic or administrative nature signs of such disputes, the problem remains unresolved.

Therefore, in our opinion, issues related to the use of this method of protection can be resolved by amending art. 392 of the Civil Code regarding the extension of the grounds for its application by such grounds as the absence of a legal document, as well as a special reservation in the procedural legislation regarding the procedure for dealing with cases on this basis in different forms of litigation and different types of proceedings.

There are also several loopholes and contradictions in the field of the protection of common partial ownership that have been identified as a result of the practice of applying Chapter 26 of the Civil Code of Ukraine. Thus, at same time, several problems arise when co-owners use art. 365 of the Civil Code of Ukraine, which regulates termination the right to part on the claim of other co-owners.

Firstly, the norm of art. 365 of the Civil Code is constructed in such way that it provides possibility of appeal against such claim only by other "co-owners" and not by "co-owner". Therefore, the question arises of the possibility of bringing to court one of the co-owners with a claim for termination of the right to share of the second co-owner, that is, if there are only two of such co-owners in the joint partial ownership.

Secondly, the question arises as to the possibility consideration of such cases in the economic process. In particular, there is no provision in the Economic Code of Ukraine that would provide for such way of termination of the right of share.

However, the jurisprudence notes the possibility of applying the provision of Art. 365 of the $\mathrm{CC}$ to relations with the participation of economic entities. Thus, the Supreme Court notes, that because "economic relationships about termination of the right to share in the joint property by court decision that based on the claim of other co-owners not governed by other legal acts than civil law, for such cases the relevant provisions of the Civil Code of Ukraine are subject to application, in particular, provisions of art. 365 of this Code"3.

The third problem is availability in case law different legal positions about that whether all four conditions must be present in the aggregate, or one or more of them at all. This is due to the fact that the article itself lists these conditions without making any reservations about their application. In the case law, there were decisions that indicated the need for these four conditions in the aggregate, but subsequently they were revised in cassation with a

${ }^{3}$ Дайджест судової практики Великої Палати Верховного Суду. № 2019/1. C. 36. URL: https://supreme.court.gov.ua/userfiles/media/daidjest_6.pdf. 
different interpretation of such grounds. The reason for implementation of such interpretation was the letter of the Supreme court of Ukraine "Analysis of some questions of the applicator by courts the legislation of property rights in the consideration of civil cases" from 01.07.2013, according to which from the norm art. 365 of the Civil Code follows that the termination of the person's right to share in the common property is allowed in the presence of any of the circumstances provided for in paragraphs 1-3 of part 1 of art. 365 of the $\mathrm{CC}$, but provided that such termination would not cause significant harm to the interests of the co-owner and his family members ${ }^{4}$. On the basis of the above, it is necessary to note the tendency to consider such disputes with the use of a similar interpretation of art. 365 CC. However, for the purpose of uniform application by the courts this provision, need to make changes to art. 365 of the Civil Code, while eliminating the contradictions laid down in the said article.

It is also difficult to determine the size of a share, in particular, the notion of a "small" share as one of the conditions for termination of the right to share.

So whether it be a small part compared to other parts of the co-owners, or just less than their shares and how much less.

The issue of a small share is usually decided by the court depending on the particular circumstances of the case. At the same time, in our opinion, it would be more expedient to make a corresponding reservation in art. $365 \mathrm{CC}$.

It should also be proven in court that the termination of a person's right to share will not materially harm the interests of the co-owner and his or her family members. The Supreme Court pointed attention to this condition to terminate the right to share, and noted the possibility of extending it to relationships involving economic entities, with the caveat, that the provisions on co-owner of interest to be applied to all property relations which arise between co-owners in common property, and reservation about "and his family" shall be applied solely to individuals as participants in these relations. " ${ }^{5}$ At the same time, it would be more effective to implement the relevant clause in art. 365 of the Civil Code regarding the interests of co-owners and family members (for individuals), as well as the interests of co-owners (for other members of civil relations).

Not devoid of gaps and the mechanism of the co-owner rights protection in case of sale share with violation of the right of pre-emptive purchase of the

4 Лист Верховного Суду України від 01.07.2013 p. URL: https://protocol.ua/ua/ analiz_deyakih_pitan_zastosuvannya_sudami_zakonodavstva_pro_pravo_vlasnosti_pri_rozglyadi _tsivilnih_sprav/

5 Постанова Великої Палати Верховного Суду України від 18.12.2018 р. у справі № 908/1754/17. URL: http://www.reyestr.court.gov.ua/Review/78977551. 
share provided by art. $364 \mathrm{CC}$, which can be summarized as follows: 1) no indication of the extension of the right of pre-emptive purchase of the share only in cases of alienation under the contract of sale; 2) an unclear mechanism of transfer of rights and obligations of the buyer. Thus, law does not oblige you to rearrange the purchase agreement with the new owner. Therefore, the court's decision to transfer the rights and obligations of the buyer to the co-owner whose rights have been violated will be considered a title deed, on the basis of which the buyer's party to the contract will be replaced, but there will be no disclaimer in the contract itself. It should be borne in mind that all the terms of such agreement must be considered valid, except for those that defined the identity of the previous buyer, who was not a co-owner. Therefore, the invalidation of a contract for the alienation of a share concluded in breach of a pre-emptive right is an inadequate means of protection.

Based on the above, it is necessary to note the expediency of taking into account the investigated gaps and contradictions in the formulation of amendments to the acts of civil law in connection with their upcoming update. At the same time, the main attention should be paid to the existing gaps and contradictions revealed in the process of application of civil law norms by the courts in the settlement of civil cases, the decision of which should be based on the achievements of civilistic science and results of court practice.

\section{Expertise of the land with the purpose of acquiring ownership}

Due diligence procedure enables you to reduce your risk and make transaction decisions based on objective information. There are several types of Due Diligence: technical, marketing, environmental, legal, economic, tax and more.

Due diligence (in english) is "due diligence, prudence". Encyclopedic English Banking Dictionary by B.G. Fedorova defines "due diligence" as a proper check and indicates that "in the work of Western investment banks, "due diligence" designates a set of actions designed to provide the project with minimal protection against disasters: a trip to a place, acquaintance with counterparties, study of the environment and places, social and other risks" It is generally accepted that a legal (law) audit is a systematic process of obtaining and evaluating the objective facts of a person's legal constituent, which establishes the level of their compliance with established law, case law and business practices.

The research of the due diligence is devoted to the scientific works of foreign scientists, in particular, J. Bower (studied the role of the merger and

\footnotetext{
${ }^{6}$ Due Diligence. URL: http://services.svdevelopment.com/ua-lawyer-audit-analiz.html
} 
acquisition acquisitions process), R. Waterman (explored ways to effectively manage the company), and authors of the balanced scorecard R. Kaplan and D. Norton, and many others. At the same time, Ukrainian studies are limited to articles on specific issues: I.M. Tkachuk examines the differences between auditing and due diligence, and the works of V.M. Likhovchuk, N.E. Silicheva, O.O. Tereshchenko and M.V. Stetskais dedicated to the prospects of developing due diligence in Ukraine. About due diligence as a kind of audit services write I.M. Gnoeva, A.O. Kasich, B.V. Melnychuk ${ }^{7}$.

In the current legislation of Ukraine there is no definition of legal (law) audit, corporate audit, and moreover the due diligence procedure, there are also no mechanisms regulating the procedure for its conduct.

It is believed that this term was put into circulation in the 1930s in the United States. At first, it meant the procedure of disclosing information to a broker before an investor about companies whose shares were traded on the open stock market. Further due diligence moved into the US banking industry. $\mathrm{He}$ had in mind a comprehensive system for collecting and analyzing information about potential or existing clients and partners, which was intended by banks to protect property from possible losses. This term refers to the independent verification of information about the issuing company for possible violations of the law, conducted with due care, which allows to limit the liability of the underwriter for errors contained in the emission of securities issue. However, the concept was not explicitly defined in the legislation because, as stated by state courts, it is not possible to establish a single volume of requirements for underwriting of due diligence of different companies.

Nowadays, the concept of legal (law) audit has become quite broad. Today, due diligence means a comprehensive investor-led audit to assess the various risks involved in investing. As a rule, it is done when deciding whether to buy a share in a business or a business project as a whole.

Sometimes a legal (law) audit or 'due diligence' is defined as the due diligence of the parties involved in preparing the agreement documents to form a credible basis for the truth and completeness of the provisions of the documents and the facts contained therein.

In some cases, this term refers to the collection and analysis of information about potential or existing clients and partners in order to assess their financial condition and reliability. The amount of legal due diligence, first of all, depends on the specificity of the asset (real estate - land, house with land,

\footnotetext{
${ }^{7}$ Безус А.М. Застосування процедури дью ділідженс як важеля зменшення інформаційних ризиків при здійсненні емісії цінних паперів. URL: http://www.investplan.com.ua/ pdf/9_2018/11.pdf
} 
separately located building, apartment, office; corporate rights to the entity that owns the property on the property right, etc.), and also the history of ownership of such an asset (how the property was purchased, for example, through privatization, construction, purchase; sole proprietor or owners changed, if so, how long ago (after the statute of limitations had expired) on which basis the property had been acquired on a quotes, or no registered owners at all, since the property is being sold as an investment, under construction).

Thus, the well established practice of due diligence the purchase of real estate and land lots.

The real estate due diligence procedure is usually carried out in several stages, during which the owner's rights to the real estate object, the history of the creation of the object, the chain of purchases, the analysis of the privatization procedure are analyzed.

Specialists also identify the actual encumbrances with which the object is for sale, carry out an expert examination of the seller's real estate transactions, establish competence and restrictions on the transaction.

Thus, due diligence of land lot includes examining the legality of the ownership and use of land, obtaining all necessary approvals and complying with the necessary procedures for their disqualification, withdrawal, change of purpose, etc., verify the legitimacy of transactions on land, setting the existing restrictions on the land, the restrictions established for agricultural land. So there are peculiarities of holding a due diligence land formed with rights. Thus, when checking the allotment (formation) of a land plot, it is necessary to check the grounds for the development of land management documentation, approval of land management documentation and its expertise, analysis of existing restrictions on land use, the establishment of geodetic parameters and topographic plans, etc. Analysis of current land use may include research into the features of the legal regime of current land use, the history of land use, establishing the impact of the current regime on the registration of land rights. When researching the history of a real estate object, all the legal documents are checked, the lawfulness of the purchase of the real estate object, information from the archives of the administrative-territorial unit, state registers, BTI registration, etc. is raised ${ }^{8}$.

In many jurisdictions, title verification is limited to formally verifying current ownership of an entity by, for example, obtaining an extract from the relevant registry. In Ukraine, this is also possible, but we have a much more acute question of historical defects that may affect the title of the current owner. This is, in particular, facilitated by the relatively weak protection of a

\footnotetext{
${ }^{8}$ URL: https://www.de-jure.ua/wp-content/uploads/2019/09/Due-diligence-obiektivnerukhomosti.pdf
} 
conscientious purchaser in the form in which it is implemented in our legislation (art. 388 of the Civil Code of Ukraine).

For the acquisition of ownership of immovable property by the statute of limitations must be given title value for a court decision recognizing ownership which is made on the basis of establishing by him the fact of possession of real estate in compliance with statutory requirements. The state registration of real estate rights in Ukraine should have only fixing nature.in this connection, one can also mention the liberal approach of the courts to vindication, which allow this method of protection without the need to deny the whole chain of ownership of the disputed object (for example, the decision of the SCU in the case No. 6-136ts12).

For example, an assetdeal is the land under the target asset that is important for the legal audit of the assetdeal. This is due both to the possibility of further use by the buyer of the purchased real estate for the intended purpose (for example, the location of parking places for visitors to the mall, the construction of warehouses for the maintenance of the commercial object, etc.), and to a purely legal an opportunity to make an assetdeal.

Thus, according to Part 2 of art. 377 of the Civil Code of Ukraine dated 16.01.2003 № 435-IV the size and cadastral number of the land plot on which the target asset is located are essential conditions for contracts that provide for the transfer of ownership of the real estate object (except for apartments in apartment buildings), if the land plot under the commercial real estate object is not furnished, then the transaction may not be possible before its proper registration. In this regard, conducting a legal audit of the land is also a prerequisite for planning a real estate transaction.

\section{Conditions of acquisition of property rights on real estate for a long timeowning}

Cases were common and remain, when a person owns certain property, building, land without being the owner of such property, without properly documented possession, owever, this has been going on for a long time. Such cases relate to villages, district centers, but are increasingly occurring in cities. As a rule, a person conscientiously and openly seized such property, that is property will improve over time at the expense of the owner's labor or money.

Despite the fact that in Art. 344 of the Civil Code of Ukraine spelled out the conditions of acquisition of the right of ownership by the statute of limitations, many questions arise regarding the conditions acquisition of ownership. Article 344 of the Civil Code defines such important conditions of limitation, as honesty of ownership; transparency of ownership; continuity of possessions (real estate for 10 years, movable property for five years); 
possession within a specified period, these conditions should apply simultaneously'.

Open ownership implies, that the purchaser of the real estate does not conceal the fact of possession and uses it as its owner. Continuity condition is characterized by the need for long and continuous possession of real estate to acquire ownership of the property for a long time ago, but it should be noted in accordance with Part 3 of Article 344 of the Civil Code of Ukraine the loss of immovable property by the owner, not of his own volition, does not interrupt the statute of limitations, if the real estate has been returned within one year, or in the event of a claim for the demand for that real estate.

French civil law in Art. 229 of the Civil Code of France requires the following conditions of acquisition of title to the statute of limitations, possession of a permanent and continuous, peaceful and open, which is undeniable and is carried out by the person in the form of the owner. Unlike the civil law of Ukraine, the French civil law establishes a 30-year statute of limitations on both movable and immovable property ${ }^{10}$.

The German Civil Code (BGB), in accordance with paragraph 943, provides for a fair use condition for the acquisition of ownership if the owner is dishonest, or later learns that the property does not belong to him, acquisition by prescription is excluded ${ }^{11}$.

In countries where there is a statute of limitations, an ancient owner is not obliged to personally own a thing for the entire period of limitation.

Such owner may attach to the term during which he owned the term of ownership of his predecessor. In accordance with Paragraph 943 of the German Civil Code (BGB), if under a succession of thing passed into the possession of a third party, who will own it as owner, then the statute of limitations that has expired during the possession of the predecessor is credited to this third party ${ }^{12}$.

A similar rule exists in the Civil Codes of the Republic of Poland, the Republic of Belarus.

Thus, it is obvious that the legislation of different countries where there is an institution of limitation, has similar conditions of acquisition of ownership of immovable property for a long time ago, differs in the number of conditions, terms of acquisition of ownership.

\footnotetext{
${ }^{9}$ Civil Code of Ukraine of May 10, 2018 (as amended and supplemented). Official Text-K. : PALIVODA AV, 2018. $408 \mathrm{p}$.

${ }^{10}$ Civil Code of France. URL: https://pandia.ru/text/77/231/34260.php

11 German Civil Code (BGB). URL: https://ru.wikisource.org/wiki/Германское_ гражданское_уложение/Книга_3/Раздел_3

${ }^{12}$ Ibid.
} 
There are a lot of questions about the acquisition of title to the land prescription. Often there is a situation where observance of all conditions of limitation does not lead to the emergence of ownership of the land.

Accordingly, to Part 3 of Article 344 of the Civil Code of Ukraine in this case, if the person took possession of the real estate on the basis of a contract with the owner of the property, who after the expiration of the contract did not make a claim for the return of his property, then that person acquires the title to the real estate after the expiration of fifteen years of possession of the real estate since the expiration of the statute of limitations. Considering also the simultaneous fulfillment of the conditions of good faith; openness, continuity of ownership and tenure for a fixed period ${ }^{13}$.

It should be noted that the acquisition of the ownership of the land plot by prescription is also regulated by Art. 119 of the Land Code of Ukraine, which states that citizens who conscientiously, openly and continuously use the land for 15 years, but who do not have documents proving that they have the rights to this land, can apply to a public authority, Council of Ministers of the Autonomous Republic of Crimea or local self-government body requesting that it be transferred into ownership or made available. The size of this land plot shall be established within the limits established by this Code $^{14}$.

In order to acquire ownership of real estate, the legal value of the property must be given legal value by a court decision on recognition of ownership, which is made on the basis of establishing by him the fact of possession of real estate in compliance with the statutory requirements. State registration of real estate rights in Ukraine should only be of a fixed nature.

\section{CONCLUSIONS}

Adaptation to the conditions of the EU internal market requires the updating of civil legislation, while simultaneously addressing the general problem of choosing between a private-law (humanitarian) approach and a public-law (state-regulatory) approach.

These circumstances should be taken into account when defining the algorithm of Ukraine's adaptation to the EU legal system (at present it looks like a legal adaptation to the conditions of the EU internal market, which is, first and foremost, in the perception and adoption of the European concept of private law).

It should be noted that it is advisable to take into account the gaps and contradictions investigated in the formulation of amendments and

${ }^{13}$ Civil Code of Ukraine of May 10, 2018 (as amended and supplemented) // offic.-text .: PALIVODA A.B.,2018.- 408 c.

${ }^{14}$ Land Code of Ukraine // URL: https://zakon.rada.gov.ua/laws/show/2768-14 
supplements to the civil legislation in connection with their future updating. At the same time, the main attention should be paid to the existing gaps and contradictions revealed in the process of application of civil law norms by the courts in the settlement of civil cases, the decision of which should be based on the achievements of civilistic science and results of court practice.

Not devoid of gaps and the mechanism of the co-owner rights protection in case of sale share with violation of the right of pre-emptive purchase of the share provided by art. $364 \mathrm{CC}$, which can be summarized as follows: 1) no indication of the extension of the right of pre-emptive purchase of the share only in cases of alienation under the contract of sale; 2) an unclear mechanism of transfer of rights and obligations of the buyer. Thus, law does not oblige you to rearrange the purchase agreement with the new owner. Therefore, the court's decision to transfer the rights and obligations of the buyer to the coowner whose rights have been violated will be considered a title deed, on the basis of which the buyer's party to the contract will be replaced, but there will be no disclaimer in the contract itself. It should be borne in mind that all the terms of such agreement must be considered valid, except for those that defined the identity of the previous buyer, who was not a co-owner. Therefore, the invalidation of a contract for the alienation of a share concluded in breach of a pre-emptive right is an inadequate means of protection.

Based on the above, it is necessary to note the expediency of taking into account the investigated gaps and contradictions in the formulation of amendments to the acts of civil law in connection with their upcoming update. At the same time, the main attention should be paid to the existing gaps and contradictions revealed in the process of application of civil law norms by the courts in the settlement of civil cases, the decision of which should be based on the achievements of civilistic science and results of court practice.

The adoption of the Civil Code of Ukraine on January 16, 2003 evidenced a fundamental change in the legal regulation of civil relations, which became the basis of the private law of an independent Ukraine. The preferred majority of the Civil code rules is characterized by high legal technique, complete regulation of civil relations. A large number of novelties were introduced for all legal institutions, including the field of property law. At the same time, 16-year practice of application of Civil Code of Ukraine norms also revealed vulnerable provisions, contradictions, which necessitated many changes to make, the analysis of which gives grounds to confirm the continuous improvement of the civil legislation.

Adaptation to the conditions of the EU internal market needs updating of civil law with a simultaneous solution to the general problem of choosing between the private (humanitarian) approach and the public-law 
(state-regulatory) approach. It is emphasized that these circumstances should be taken into account when defining the algorithm of adaptation of Ukraine to the EU legal system (at present it looks like a legal adaptation to the conditions of the EU internal market, which is, first and foremost, in the perception and adoption of the European concept of private law). At the same time, the problems of ideological and mental compatibility must also be resolved, without which the desired result of adaptation of justice, legal understanding, legal doctrine, legislation and, finally, the concept of law (in particular, private law) cannot be achieved.

The monograph deals with some aspects of civil legislation recodification in the context of European integration processes, in particular: prospects for updating the civil legislation of Ukraine in the field of property rights protection, expert report of land field for the purpose of realization of transactions on the acquisition of property rights, as well as the peculiarities of acquiring property rights for real estate property by the statute of limitations.

Keywords: civil law, recodification, property, property rights, acquisition of property rights, statute of limitations.

\section{SUMMARY}

The adoption of the Civil Code of Ukraine on January 16, 2003 evidenced a fundamental change in the legal regulation of civil relations, which became the basis of the private law of an independent Ukraine. The preferred majority of the Civil code rules is characterized by high legal technique, complete regulation of civil relations. A large number of novelties were introduced for all legal institutions, including the field of property law. At the same time, 16-year practice of application of Civil Code of Ukraine norms also revealed vulnerable provisions, contradictions, which necessitated many changes to make, the analysis of which gives grounds to confirm the continuous improvement of the civil legislation.

Adaptation to the conditions of the EU internal market needs updating of civil law with a simultaneous solution to the general problem of choosing between the private (humanitarian) approach and the public-law (stateregulatory) approach. It is emphasized that these circumstances should be taken into account when defining the algorithm of adaptation of Ukraine to the EU legal system (at present it looks like a legal adaptation to the conditions of the EU internal market, which is, first and foremost, in the perception and adoption of the European concept of private law). At the same time, the problems of ideological and mental compatibility must also be resolved, without which the desired result of adaptation of justice, legal understanding, legal doctrine, legislation and, finally, the concept of law (in particular, private law) cannot be achieved. 
The monograph deals with some aspects of civil legislation recodification in the context of European integration processes, in particular: prospects for updating the civil legislation of Ukraine in the field of property rights protection, expert report of land field for the purpose of realization of transactions on the acquisition of property rights, as well as the peculiarities of acquiring property rights for real estate property by the statute of limitations.

\section{REFERENCES}

1. Civil Code of France. URL: https://pandia.ru/text/77/231/34260.php

2. Civil Code of Ukraine of May 10, 2018 (as amended and supplemented). Official Text. K. : PALIVODA AV, 2018. 408 p.

3. German Civil Code (BGB). URL: https://ru.wikisource.org/wiki/ Германское_гражданское_уложение/Книга_3/Раздел_3

4. Land Code of Ukraine. URL: https://zakon.rada.gov.ua/laws/show/2768-14

5. Due Diligence. URL: http://services.svdevelopment.com/ua-lawyeraudit-analiz.html

6. URL: https://www.de-jure.ua/wp-content/uploads/2019/09/Due-diligenceobiektivnerukhomosti.pdf

7. Безус А.М. Застосування процедури дью ділідженс як важеля зменшення інформаційних ризиків при здійсненні емісії цінних паперів. URL: http://www.investplan.com.ua/pdf/9_2018/11.pdf

8. Дайджест судової практики Великої Палати Верховного Суду. № 2019/1. C. 36. URL: https://supreme.court.gov.ua/userfiles/media/ daidjest_6.pdf.

9. Дзера I.О. Деякі питання визнання права власності за статтею 392 Цивільного кодексу України. Підприємниитвво, господарство і право. 2018 № 5. C.19-24.

10. Лист Верховного Суду України від 01.07.2013 p. URL: https://protocol.ua/ua/analiz_deyakih_pitan_zastosuvannya_sudami_zakonoda vstva_pro_pravo_vlasnosti_pri_rozglyadi_tsivilnih_sprav/

11. Постанова Великої Палати Верховного Суду України від 18. 12.2018 р. у справі № 908/1754/17. URL: http://www.reyestr.court.gov.ua/ Review/78977551.

\section{Information about the author: Safonchik O. I.,}

Doctor of Law, Professor of the Department of Civil Law National University "Odesa Law Academy" Fontan road 23, Odesa, Ukraine ORCID ID: https://orcid.org/0000-0001-6781-8219 